\title{
Utilization of Various Disruptive Community Learning Resources for the Covid-19 Period in the Perspective of Life Based Learning
}

\author{
https://doi.org/10.3991/ijim.v15i07.21551 \\ Hardika Hardika ${ }^{(\varpi)}$, Eny Nur Aisyah, R. Anggia Listyaningrum \\ Universitas Negeri Malang, Malang, Indonesia \\ hardika.fipeum.ac.id
}

\begin{abstract}
This study aims (1) to analyze the use of various disruptive community learning resources during the Covid-19 period in terms of characteristics, levels, and types of learning resources used by lecturers in lectures, and (2) to find out the differences in the use of various disruptive community learning resources during the Covid-19 period between fields of science at Universitas Negeri Malang. The research approach used quantitative with an ex post facto design. The respondents of this research were 393 students of Universitas Negeri Malang from eight faculties. The data was collected through a closed questionnaire distributed through the Google Form application technology. Data analysis was performed by using percentage description statistics and different tests of the use of learning resources between the sciences, social humanities, and engineering. The results of the analysis show that (1) the characteristics, levels, and types of disruptive community learning resources in the Covid-19 era used by lecturers in lectures vary widely, (2) there are significant differences in the use of various disruptive community learning resources during the Covid-19 period between science and social humanities students, and engineering.
\end{abstract}

Keywords - Community Learning Resources, Fields of Science, Life Based Learning

\section{Introduction}

The very rapid presence of information technology has changed people's behaviour in various lives [1]. Likewise, the emergence of the Covid-19 pandemic has provided an impetus for accelerating the implementation of new life governances [2]. Lifebased learning is one of the centers of study in lecture management, both in the aspects of planning, implementation, monitoring, and evaluation. In this context, one of the important elements in learning is the use of a variety of learning resources that are adaptive to the disruptive era in the Covid-19 era [3]. Learning resources are a dominant part of the entire learning process [4]. The existence of learning resources will provide a foundation for lecturers to explore and develop scientific information [5]. The flow of learning information development also departs from the strength of 
the learning resources used in learning activities [6]. Thus, learning resources become the centre of scientific study and development activities which are targets of student learning outcomes.

Acquisition and selection of learning resources in lectures can be done using the principles of relevance, efficiency, effectiveness, affordability, appropriateness, and accuracy [7]. Implementation of all these principles in the selection and acquisition of learning resources will affect the quality of learning resources [8]. Good quality learning resources will have a positive impact on the learning behaviour of the learner [9]. The learning behaviour of the learners will determine the level of learning achievement, both concerning instructional and accompaniment outcomes [10]. Both of these achievements will contribute to the formation of scientific character and student maturity. In fact, in the practice of life in society, learning outcomes in the form of side effects often determine success and survival. [11].

In modern learning, what is meant by learning resources is not just physical teaching materials in the form of learning material tools, but is a whole learning device that can provide enlightenment, provision, enrichment, and motivation for students to be able to learn creatively [12]. Thus, teaching materials in this context can be in the form of software and hardware. The software can be messages, strategies, patterns, motivation, facilitation, inspiration, and various creations, cultures, and folklore [13]. Meanwhile, learning resources in the form of hardware include electronic equipment, printed materials, nature, and everything in them including humans [14]. Of course, each of these learning resources has different characteristics when used in lectures. Therefore, the role of lecturers in creating and improvising these learning resources is to be more effective and attractive.

In a review of information technology-based learning, learning tools must also prioritize the principles of ease, speed, flexibility, and adaptability to various situations [15]. The use of mobile interactive media is an inevitable demand for learning[16]. Thus, all types and models of instructional media must always be based on the principles mentioned above. Likewise, those related to learning resources, of course, must also be connected with the principle of mobile interactive materials. The capacity of educators must be increased in mastering skills in using and creating interactive car-based learning media and resources[17].

In the study of learning resources, there are various conceptions and definitions according to the intended use of these learning resources [18]. Non-material and nonphysical learning sources will provide reinforcement, motivation, and inspiration for learning participants to create and innovate [19]. Thus, learning resources in lectures can be interpreted as materials, materials, strategies, methods, and learning techniques that can inspire learning participants to create and innovate according to the times. [20].

The foresight and intelligence of the lecturer in choosing and using learning resources in lectures will determine the continuity and success of learning [12]. The selection and use of learning resources that are not relevant to the disruptive era will certainly not get an adequate response from learning participants [18]. Likewise, the selection and use of learning resources that are not relevant to the Covid-19 pandemic period also did not get a positive response from the learning participants. This is 
because of the disruptive era and the emergence of the Covid-19 outbreak has changed the order and patterns of human behaviour including learning activities \{Formatting Citation\}. The roles of educators and students have changed along with the change in the learning paradigm as a result of the development of information technology and also triggered by the COVID-19 pandemic. [3].

The learning activity which is the study of this research is life-based learning. Lifebased learning in this study emphasizes the exploration of problems and student learning experiences as learning resources that can inspire student creativity in their lives. The exploration of student learning experiences and problems includes five learning dimensions, namely (1) learning experiences to foster positive perceptions and attitudes, (2) building knowledge, (3) expanding knowledge, (4) using knowledge correctly, and (5) forming productive thinking habits [23]. The five learning dimensions are used as a basic framework in the formulation of life-based learning. Thus the role of educators must be reviewed, especially related to their role as facilitators and motivators of learning who must be able to provide creative and innovative inspiration to students [24].

This research will answer how lecturers choose and use learning resources in lectures in this disruptive and COVID era. These two incidents have become phenomenal because they have changed the governance of world life, including education actors. Education must be immediately organized and reformulated with the planning, process, and evaluation of learning so that it continues to exist and take place normally. An analysis of the use of a variety of learning resources that are adaptive to the disruptive era will provide important information in structuring learning management that is relevant to the COVID-19 pandemic situation.

\section{Research Methodology: Data and Sample Size}

It should be understood that this study aims to identify and explain the use of disruptive community learning resources during the Covid-19 pandemic in terms of, characteristics, levels, and types of learning resources used in lectures at Universitas Negeri Malang. The research approach used quantitative with an ex post facto design. The respondents of this study were 393 students of Universitas Negeri Malang from eight faculties in the 2016/2017, 2017/2018, 2018/2019, and 2019/2020 input years, with an average number of respondents in each faculty of 49 people. The data was collected using a closed questionnaire distributed through the Google Form application technology. The item validity test was carried out through the Pearson Correlation technique by taking a sample of 50 outside the research respondents with a significance level of 0.05 . All items in the instrument were declared valid with a significance level above 0.05 . The reliability test used Cronbach's technique it is known that the instrument is declared reliable because the sig value is $0.742>0.60$. The data normality test was performed using the One-Sample Kolmogorov-Smirnov Test statistical technique. The sample data is known to come from a normally distributed population with a sig.0.080 $>0.05$. The homogeneity test of the data using the Test of Homogeneity of Variances shows that the data is homogeneous with a sig. 
$0.061>0.05$. Data analysis was carried out by using the percentage description statistical technique and the One-Way ANOVA difference test on the use of learning resources between the fields of science, social humanities, and engineering.

\section{$3 \quad$ Findings and Discussion}

This study aims to identify and explain the use of disruptive community learning resources during the Covid-19 pandemic in terms of, characteristics, levels, and types of learning resources used in lectures at the State University of Malang. The research approach used quantitative with an ex post facto design. The respondents of this study were 393 students of Universitas Negeri Malang from eight faculties in the 2016/2017, 2017/2018, 2018/2019, and 2019/2020 input years. The data was collected using a closed questionnaire distributed through the Google Form application technology.

The item validity test was carried out through the Pearson Correlation technique by taking a sample of 50 outside the research respondents with a significance level of 0.05 . All items in the instrument were declared valid with a significance level above 0.05 . The reliability test used Cronbach's technique it is known that the instrument is declared reliable because the sig value result is $0.742>0.60$. The data normality test was performed using the One-Sample Kolmogorov-Smirnov Test statistical technique. The sample data is known to come from a normally distributed population with a sig.0.080> 0.05. The homogeneity test of the data using the Test of Homogeneity of Variances shows that the data is homogeneous with a sig. 0.061> 0.05 . Data analysis was carried out by using the percentage description statistical technique and the One Way-ANOVA difference test on the use of learning resources between the fields of science, social humanities, and engineering.

Table 1. Profile Research Subject Based on Utilization of Various Disruptive Learning Resources in the Covid-19 Period of All Faculties at State University of Malang

\begin{tabular}{|l|c|c|c|c|}
\hline & $\begin{array}{c}\text { The } \\
\text { Characteristics } \\
\text { of Learning } \\
\text { Resources Used } \\
\text { by Lecturers } \\
(\mathbf{\%})\end{array}$ & $\begin{array}{c}\text { The Level of } \\
\text { Learning } \\
\text { Resources Used by } \\
\text { Lecturers (\%) }\end{array}$ & $\begin{array}{c}\text { The Kinds of } \\
\text { Learning } \\
\text { Resources Used } \\
\text { by Lecturer } \\
\mathbf{( \% )}\end{array}$ & $\begin{array}{c}\text { Average } \\
\text { Score (\%) }\end{array}$ \\
\hline Faculty of Letter & 16 & 16 & 18 & 16,67 \\
\hline Faculty of Sport Science & 12 & 12 & 13 & 12,34 \\
\hline Faculty of Economic & 0 & 1 & 1 & 0,67 \\
\hline Faculty of Mathematics and Science & 1 & 1 & 1 & 1 \\
\hline Faculty of Engineering & 7 & 7 & 9 & 7,67 \\
\hline Faculty of Psychology Education & 8 & 6 & 9 & 7,67 \\
\hline Faculty of Social Science & 14 & 14 & 16 & 14,67 \\
\hline Faculty of Education & 41 & 43 & 34 & 39,34 \\
\hline TOTAL & $\mathbf{1 0 0}$ & $\mathbf{1 0 0}$ & $\mathbf{1 0 0}$ & $\mathbf{1 0 0}$ \\
\hline
\end{tabular}


Based on Table 1 can be explained, that the Faculty of Education was able to achieve the highest percentage score in the use of disruptive community learning resources during the Covid-19 period, namely 39.34\%. The next sequence is the Faculty of Letters, the Faculty of Social Sciences, the Faculty of Sport Sciences, the Faculty of Engineering and the Faculty of Psychology Education, and finally the Faculty of Mathematics and Natural Sciences.

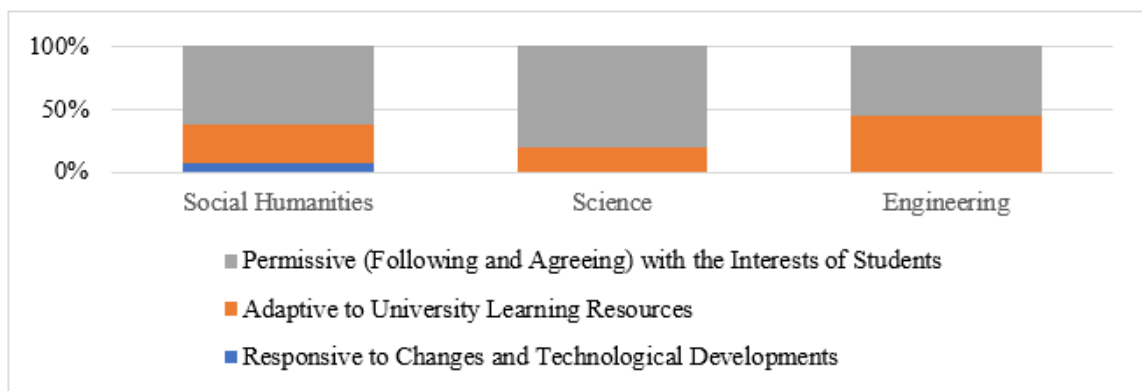

Fig. 1. Graph of the Characteristics of Disruptive community learning resources in the COVID Period between Groups of Social Humanities, Science, and Engineering.

In Fig 1, it can be explained that the characteristics of the various uses of disruptive community learning resources during the Covid-19 period between groups of disciplines are relatively varied, but have the same tendency. Learning resources with permissive character dominate the three fields of science with different percentages, namely science $78 \%$, engineering $57 \%$, and social humanities $63 \%$. The freedom of students to choose and utilize learning sources that are considered relevant to their needs and adaptive to the current era has received a positive response from the lecturer. The sequence for the use of various learning resources is adaptive learning resources to the availability of learning resources that are already owned by the university. Sequentially, the groups in the fields of engineering, social, humanities, and science make use of learning resources based on adjusting themselves to the availability of learning resources that are owned by the institution. The character of learning resources that are relevant to the latest developments, namely learning resources that are responsive to changes and developments in adaptive information technology in the disruptive era reaches $7 \%$ of the use of lecturers from the social humanities group. 


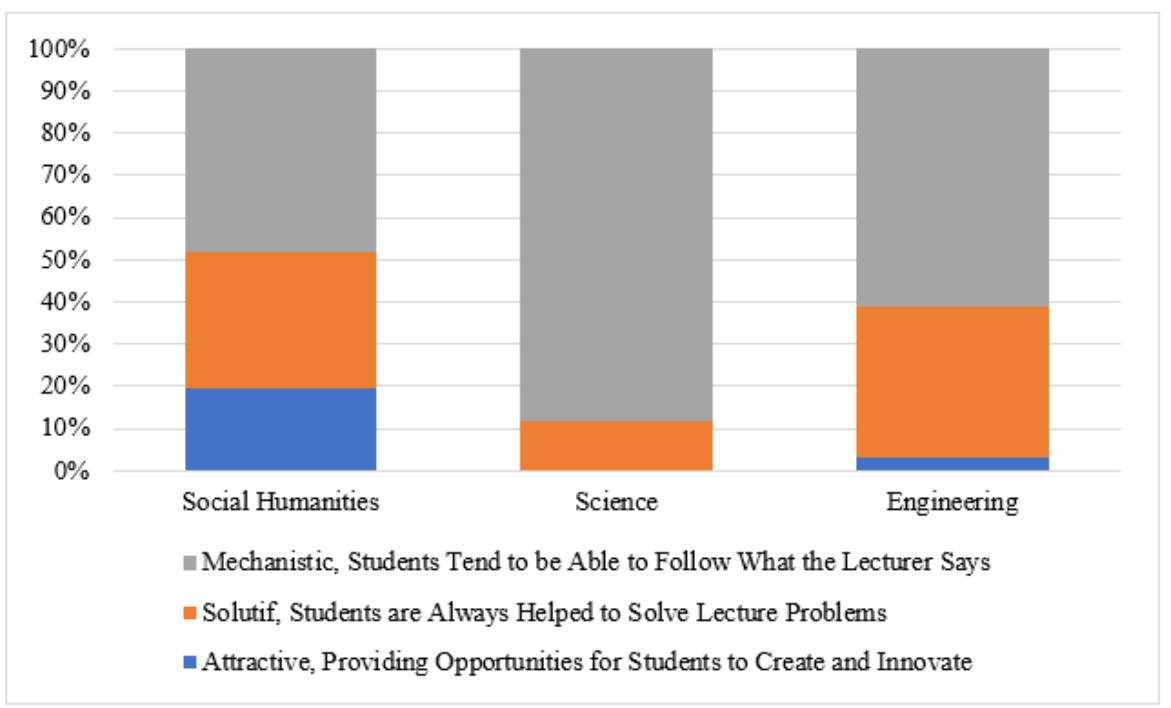

Fig. 2. Levels of Disruptive Learning Resources in the COVID Period Between Groups of Fields of Science

Fig 2 above, shows that students become followers of what the lecturer said. This level of learning resources is prioritized on the student's ability to memorize and follow the lecturers' explanations in lectures. Lecturer oral information in lectures is the main learning resource in the lecture process, both in the social, social humanities, science, and engineering groups. The field of science dominates the use of teaching resources based on oral information from lecturers during lectures, followed by engineering and social humanities. Meanwhile, the level of teaching materials based on providing solutions and problem solving was selected and used by the engineering and social humanities group lecturers, namely $25-30 \%$. The peak level and ideal level of the variety of adaptive learning resources in the disruptive era, namely learning resources that are attractive and provide opportunities for students to be creative and innovative, are only carried out by lecturers in the social sciences, social humanities, and engineering fields with a percentage of only $3-20 \%$. 


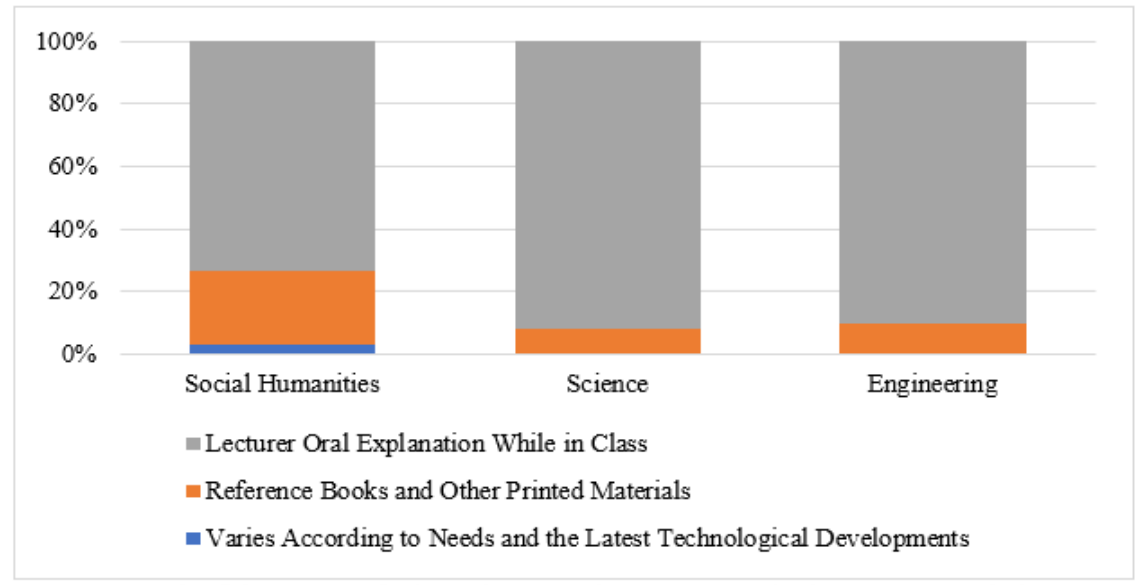

Fig. 3. Graph of the Types of Disruptive Learning Resources in the COVID Period Between Groups of Scientific Fields

As with the Fig 3 data previously described, the majority of these types of disruptive community learning resources in the COVID era still use learning resources that are less adaptive to the disruptive era. Figure 3 shows that lecturers from the three fields of science, namely social humanities, science, and engineering still select and use types of learning resources that are not adaptive to the development of the disruptive era. Lecturer oral messages in learning become the core learning resource in lectures. Students must be able to listen to, follow, analyze, and develop knowledge from oral information which is used as a learning resource. The second type of learning resources used by lecturers was printed books and other printed teaching materials. The types of learning resources that were considered the most adaptive to the disruptive era were only used by lecturers from the social humanities group, with a score percentage of $2.5 \%$. The results of the research summary can be seen in the following graphic presentation. 


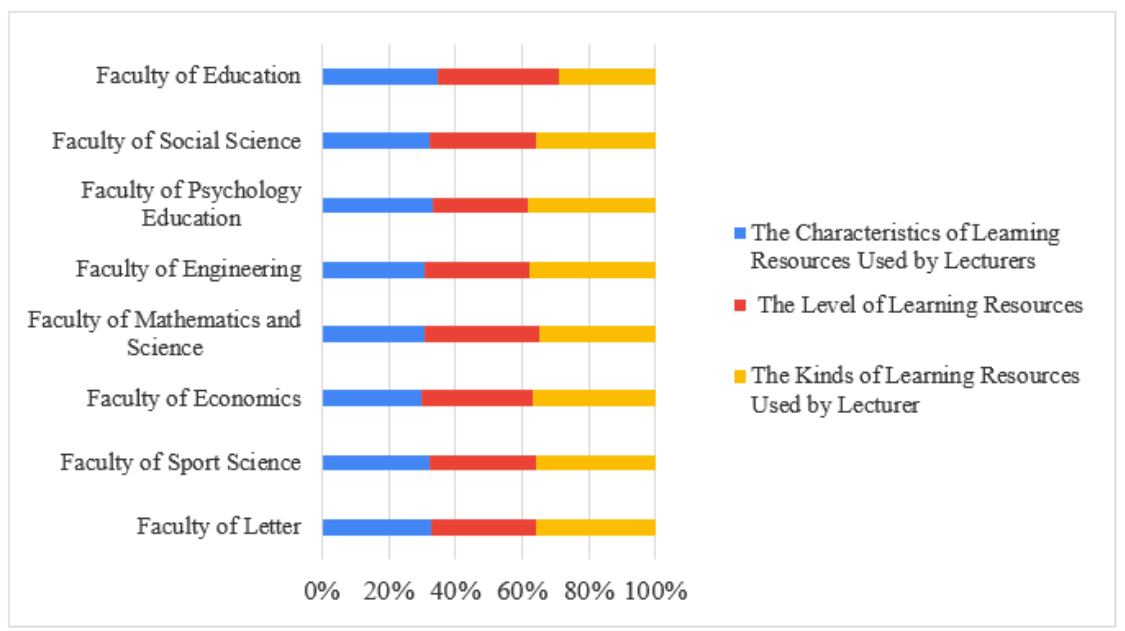

Fig. 4. Scores of the Variety of Adaptive Learning Resources in the Disruptive Era in the COVID Period for Each Faculty

The data in Fig 4 shows that each faculty gets a different score. The highest achievement was obtained by the Faculty of Education with a score of 345 (39.34\%), while the lowest was obtained by the Faculty of Economics with a score of $6(0.67 \%)$, followed by the Faculty of Mathematics and Natural Sciences with a total score of 11 $(1 \%)$. The average score was obtained by two faculties, namely the Faculty of Psychology Education 87 (7.67\%) and the Faculty of Engineering with a total score of $88(7.67 \%)$. From these data, it can be concluded that there is an extreme score interval between the highest and lowest scores. This can happen because the visions and missions of learning between faculties are indeed different and lecturers' understanding of the nature of learning resources varies greatly.

Judging from the comparison of percentage scores, the Faculty of Education dominated the highest achievement for the three aspects of learning resources used by disruptive era lecturers during the COVID era, namely (1) characteristics of learning resources $(41 \%)$, (2) level of learning resources (43\%), and (3) types of learning resources (34\%). The lowest achievement was experienced by the Faculty of Mathematics and Natural Sciences, namely $1 \%$ for the three sub-variables, both on the sub-variable characteristics, level, and the type of learning resources used by the lecturers. As for the results of the different test analysis using the One-Way ANOVA statistical technique, it is known that there are differences in the use of various disruptive community learning resources between groups in the social, human, science, and engineering fields at Universitas Negeri of Malang with a significance level of 0.01 . Whereas in the lecture implementation process the learning interaction process took place varied, the following is the explanation of the data found 


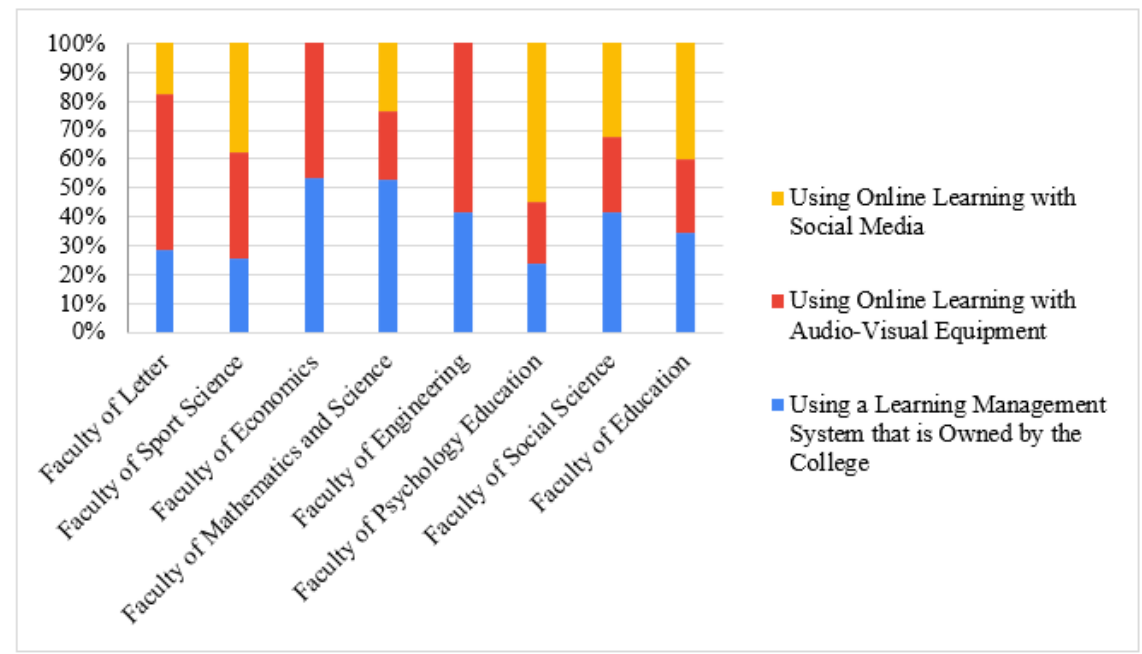

Fig. 5. The Learning Interaction Process

In Fig. 5 it appears that the lecture process using online learning dominates almost all faculties in various scientific families. Especially the Faculty of Letter and Faculty of Engineering, which tend to use online without audio-visual equipment. Meanwhile, the learning process using social media is dominated by the Faculty of Education. This is interesting because the learning media hardware they use also varies, namely personal computers, smartphones, and cellphones as the findings of the following research data exposure.

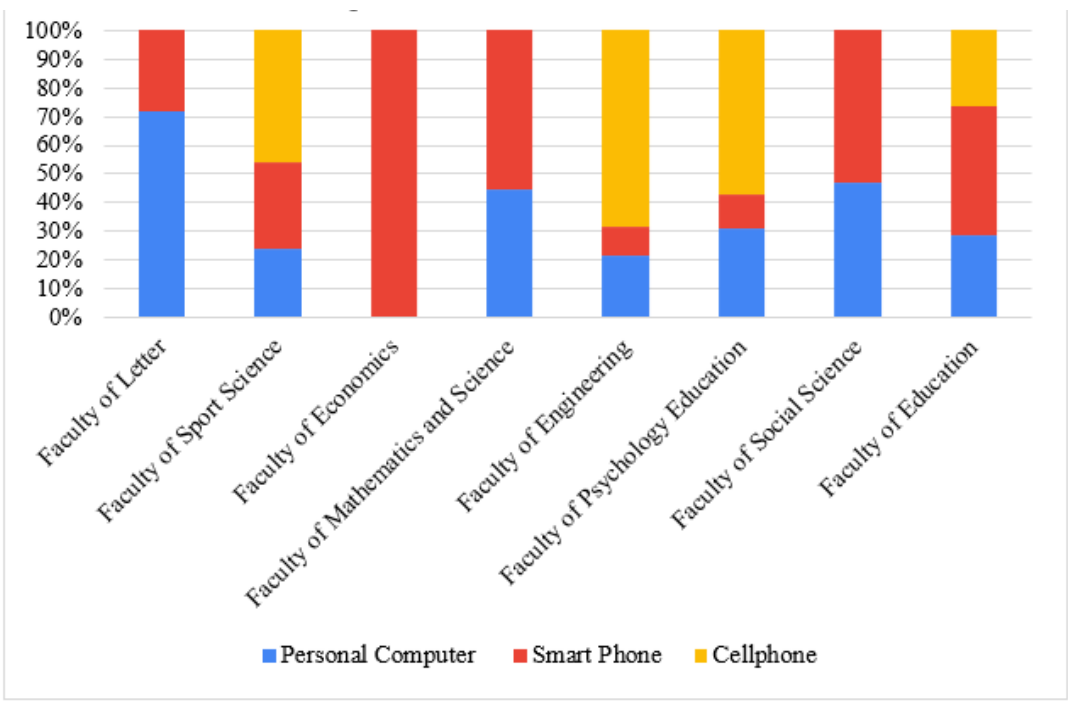

Fig. 6. The Media Used in the Learning Process 
In Fig 6, it can be seen that compared to the economics faculties that use smartphones, the faculty of engineering and faculty of psychology tend to use cellphones. The use of personal computers is more dominated by faculty of letters, faculty of social and faculty of mathematic. Based on these data, the media software used during the learning process varies from application software as WhatsApp, Telegram, Instagram, etc.

The difference in the use of various disruptive community learning resources in lectures is, in essence, a natural thing and often occurs in lecture practice [25]. Each lecturer has the authority to select and determine learning sources that are considered relevant to the objectives of the lecture. Each lecturer also has a different understanding of learning resources that are considered disruptive and relevant during the Covid-19 period. Differences in perspective and understanding of the nature of these learning resources have led to variations in learning resources in lecture practice. Likewise, the ownership of authority in the selection of learning resources has also created differences in designing and formulating the learning implementation process and its supporting tools [26].

The problems that arise are related to the context of life-based learning and student learning needs, the existence of learning resources in lectures is very vital [27]. The existence of learning resources will determine the scientific tools that students will master and their mastery of life's problems [28]. Learning resources that master adaptive to life and problems in people's lives will certainly foster students' sensitivity to various social events that occur in their environment [29]. Students will be more critical and creative about the social phenomena they face as a result of the power of inspirational learning resources used by lecturers through lecturing [30], [31].

In the view of life-based learning, the use of various learning resources in lectures must be based on the essential needs of students, and the availability of community environmental resources [32]. The selection and use of learning resources must have a direct contribution to the development and growth of potential community resources, both natural and human potential [33]. The natural potential will develop when learning is always connected to the surrounding natural environment through the use of resources to support the implementation of learning programs [34]. The potential of human resources will be an integral part of the development and creation of learning resources [35]. In this context, life-based learning will develop and run linearly with the social life of the community.

One of the pillars of using learning resources in the implementation of life-based learning is the relevance of learning programs to community needs [5]. Community needs must always be used as a reference in the formulation of learning resources, especially those related to the presentation of learning messages and their delivery strategies. [36], [37]. Many learning messages are spread in the community, both learning messages related to cultural preservation, local wisdom-based behaviour, survival strategies, togetherness attitudes, and other social activities. [38]. Learning interactions in tertiary institutions must always try to land and be in direct contact with community sources and problems [39].

The connection between universities and the community in various educational activities will create growth centers based on innovation and creation [32]. Likewise, 
higher education institutions will also have the flexibility to design and formulate a curriculum that is adaptive to the needs of the community. Community needs will be lifted through various learning program activities on campus as well as fact-based community service activities and community social problems [40], [41].

In this disruptive and COVID era, the role of lecturers in selecting and utilizing learning resources is very important, because it will have an impact on the level of learning achievement [42]. Learning outcomes in this context can be in the form of successful graduation, subject grade achievement, increased critical power, increased maturity in attitude and behaviour, readiness to compete, readiness to fail and succeed, readiness to anticipate change, and readiness to continue learning and learning again. [43]. Lecturers are required to be able to select and use learning resources that are adaptive to the individual and social characteristics of learning participants, developments in information technology, and challenges for the present and future [44].

Besides the faculty factor, the difference in the use of various learning resources between the social sciences, social humanities, science, and engineering groups is also determined by the vision and mission of each faculty. More than that, each study program also has a different vision and mission, thus giving birth to different learning patterns. For lecturers who have adequate scientific capacities and capabilities, of course, these lecturers will still be able to provide weighted learning resources following the demands of the times. [45]. However, for lecturers who do not understand the scientific vision and understanding of changes, the relevant lecturer will experience difficulty translating technological changes into lecture learning resources.

Regarding the different understandings of lecturers about the nature of disruptive community learning resources, the role of the institution needs to improve and strengthen the quality of lecturers [4]. Improving and strengthening the quality of lecturers is directed at understanding the vision and mission of the institution and efforts to achieve it through improving lecture-performance [44]. This is very important because learning performance is one of the indicators in determining higher education excellence. The quality of learning performance is measured by the quality of the learning resources that are the material for student discussion and dialogue [46]. Lecturers must have the same vision about the quality of learning resources that are adaptive to changes that occur in the current era. The characters, levels, and types of learning resources must be linear with the demands of the disruptive changes [47].

The disruptive era is characterized by competition based on creativity, convenience, openness, competition, innovation, speed, accuracy, satisfaction, benefits, and benefits for many people [29]. In this situation, of course, the variety of learning resources chosen by the lecturer in lectures must also be responsive to these disruptive aspects. Learning materials and resources are not allowed to be based solely on enjoyment and affordability, whether from the faculty, students, or institutions [48]. All learning resources must be made available even though they require funding and difficult thinking.

Connectivity between institutional units and learning elements must be good, to produce a quality performance process flow. The institutional support system must 
also be strengthened with qualified human resources following their respective fields of expertise [49]. Likewise, learning support systems, especially those related to the availability of learning communication devices and networks, must be built with anticipatory and adaptive principles to developing information technology. [50].

The problem of using various learning resources and strategies for strengthening learning performance can be described in the following scheme.

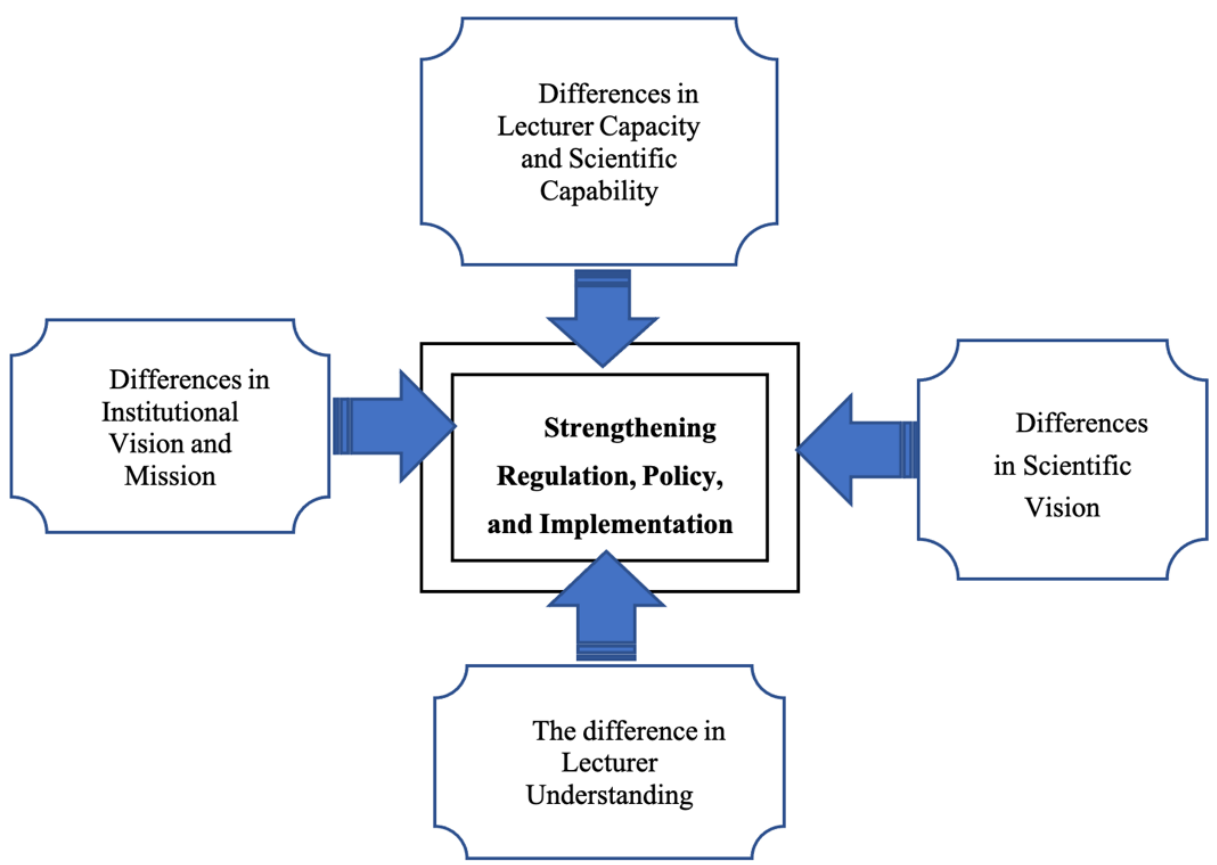

Fig. 7. The Scheme of Using Various Learning Resources and Strategies for Strengthening Learning Performance Problem

Institutional policies are needed to improve learning performance [51]. Strengthening regulation and consistent implementation needs in the process of improving the performance of all elements of the university [30]. The provision of completeness to support student learning resources is needed to give freedom to lecturers and students in designing a credible learning resource [52]. Credible learning resources will produce superior scientific achievements in all lines of assignment [53].

Learning resources in the form of software and hardware must run linearly and function in an integrated manner [29]. Characteristics of learning resources are based on efforts to occur responsive to changes in society [54]. The level of learning resources must be able to lead participants to learn towards attractive learning behaviour and solutions to the various problems of life [55]. Types of learning resources must emphasize to meet student learning needs that are varied and relevant to the development of technology and information science. All existing learning 
resources must manage in an integrated manner based on the principles of usefulness, adequacy, affordability, and excellence.

\section{Conclusion}

The use of various disruptive community learning resources during the Covid-19 period in the social sciences, humanities, science, and engineering groups varied greatly. However, it consistently explained that the use of learning resources that are adaptive and relevant to the Covid-19 situation is still using less disruptive community learning resources. This deficiency is evident in the weakness of learning actors in utilizing the potential and resources of the university as a learning resource center and community. The potential of students has not been explored optimally so that the role of lecturers is still very dominant in controlling and intervening in learning interactions. In general, there are differences in the use of various disruptive community learning resources during the COVID period between the social humanities, science, and engineering. This difference occurs due to factors of differences in institutional vision and mission, scientific vision, and understanding of lecturers in translating the disruptive era in the Covid-19 era in the context of learning.

\section{Acknowledgement}

We are very grateful to all those who have contributed to being involved in completing quantitative research with this ex post facto design. Especially to the members of the Research Team and all elements at the State University of Malang Indonesia who have helped a lot in extracting the research data we needed.

\section{$6 \quad$ References}

[1] K. R. Lee, "Impacts of Information Technology on Society in the new Century," 2017.

[2] R. Djalante et al., "Review and analysis of current responses to COVID-19 in Indonesia: Period of January to March 2020,” Prog. Disaster Sci., vol. 6, p. 100091, Apr. 2020, https ://doi.org/10.1016/i.pdisas.2020.100091.

[3] Z. Zaharah and G. Kirilova, "Impact of Corona Virus Outbreak Towards Teaching and Learning Activities in Indonesia," SALAM J. Sos. dan Budaya Syar-i, vol. 7, Mar. 2020, https://doi.org/10.15408/sjsbs.v7i3.15104.

[4] M. Elfert, "Lifelong learning in Sustainable Development Goal 4: What does it mean for UNESCO's rights-based approach to adult learning and education?," Int. Rev. Educ., vol. 65, no. 4, pp. 537-556, Dec. 2019, https://doi.org/10.1007/s11159-019-09788-Z.

[5] L. Margalef and N. Pareja Roblin, "Unpacking the roles of the facilitator in higher education professional learning communities,” Educ. Res. Eval., vol. 22, no. 3-4, pp. 155172, May 2016, https://doi.org/10.1080/13803611.2016.1247722.

[6] C. Ullrich, "The learning-resource-type is dead, long live the learning- resource-type!," Learn. Objects Learn. Des., 2005. 
[7] B. Burnes, C. Cooper, and P. West, "Organisational learning: the new management paradigm?” Manag. Decis., vol. 41, no. 5, pp. 452-464, 2003, https://doi.org/10.1108/002 $\underline{51740310479304 .}$.

[8] P. Serdyukov, "Innovation in education: what works, what doesn't, and what to do about it?,” J. Res. Innov. Teach. Learn., vol. 10, no. 1, pp. 4-33, Dec. 2017, https://doi.org/10.11 08/jrit-10-2016-0007.

[9] F. Quinn and S. Stein, "Relationships between learning approaches and outcomes of students studying a first-year biology topic on-campus and by distance," High. Educ. Res. Dev., vol. 32, no. 4, pp. 617-631, Aug. 2013, https://doi.org/10.1080/07294360.2012.704 902.

[10] Hardika, "Improving Student Learning Independence through Transfer of Learning Strategies," 2019, https://doi.org/10.2991/icet-18.2018.10.

[11] W. Widodo, S. Mundzir, A. Fatchan, and H. Hardika, "Analysis of Non-Formal Education Leadership,” Jan. 2017, pp. 230-235, https://doi.org/10.2991/nfe-16.2017.60.

[12] H. Hardika, E. Nur Aisyah, K. Miroso Raharjo, and D. Umnia Soraya, "Transformation the Meaning of Learning for Millennial Generation on Digital Era," Int. J. Interact. Mob. Technol., vol. 14, no. 12, pp. 69-81, Jul. 2020, https://doi.org/10.3991/ijim.v14i12.15579.

[13] R. M. Schwarz, The Skilled Facilitator: A Comprehensive Resource for Consultants, Facilitators, Managers, Trainers, and Coaches, 3. Hoboken, New Jersey: Jossey-Bass, 2016. https://doi.org/10.1002/9781119176572

[14] F. Rohman and A. Fauzan, "Project, Technology And Active (Protective) Learning Model To Develop Digital Literacy Skills In The 21st Century," Int. J. Sci. Technol. Res., vol. 9, p. 1, 2020, Accessed: Sep. 22, 2020. [Online]. Available: www.ijstr.org.

[15] V. Teymurova, M. Abdalova, S. Babayeva, V. Huseynova, E. Mammadov, and N. Islamova, "Implementation of Mobile Entrepreneurial Learning in the Context of Flexible Integration of Traditions and Innovations," Int. J. Interact. Mob. Technol., vol. 14, no. 21, pp. 118-135, Dec. 2020, https://doi.org/10.3991/ijim.v14i21.18445.

[16] K. Zhampeissova and I. Kosareva, "Collaborative Mobile Learning with Smartphones in Higher Education,” Int. J. Interact. Mob. Technol., vol. 14, no. 21, pp. 4-18, Dec. 2020, https://doi.org/10.3991/ijim.v14i21.18461.

[17] K. Mingsiritham, G. Chanyawudhiwan, and C. Paiwithayasiritham, "Factor Analysis of Smart Social Media Technology to Promote Professional Learning Communities for Teachers," Int. J. Interact. Mob. Technol., vol. 14, no. 20, pp. 165-173, Dec. 2020, https:// doi.org/10.3991/ijim.v14i20.17253.

[18] R. Zainul et al., "Development of e-Learning Courses for Subjects about 'Learn and Learning' with Moodle-based for Prospective Teacher in Indonesia,’ J. Phys. Conf. Ser., vol. 1594, no. 1, p. 012023, Jul. 2020, https://doi.org/10.1088/1742-6596/1594/1/012023.

[19] M. Dahlén, L. Friberg, and E. Nilsson, "Long live creative media choice: The medium as a persistent brand cue," J. Advert., vol. 38, no. 2, pp. 121-129, 2009, https://doi.org/10.27 53/joa0091-3367380208.

[20] M. Huxham, M. Hunter, A. McIntyre, R. Shilland, and J. McArthur, "Student and teacher co-navigation of a course: following the natural lines of academic enquiry," Teach. High. Educ., vol. 20, no. 5, pp. 530-541, Jul. 2015, https://doi.org/10.1080/13562517.2015.103 $\underline{6730}$.

[21] M. Snow Andrade, "A Responsive Higher Education Curriculum: Change and Disruptive Innovation," Innovations in Higher Education - Cases on Transforming and Advancing Practice. Dec. 30, 2020, https://doi.org/10.5772/intechopen.80443.

[22] H. C. Lucas, "Disrupting and Transforming the University," in Technology and the Disruption of Higher Education, World Scientific, 2016, pp. 135-136. 
[23] R. J. Marzano, A Different Kind of Classroom: Teaching with Dimensions of Learning. INSTITUTION Association for Supervision and Curriculum Development Y. iA hepruoucLions supplieo by tukb are the best th. 1992.

[24] N. Winstone and D. Carless, Designing Effective Feedback Processes in Higher Education: A Learning-Focused Approach. Routledge, 2019. https://doi.org/10.4324/9781351115940$\underline{1}$

[25] Deloitte, "Patterns of disruption," Deloitte Insights, no. November, p. 34, 2015, [Online]. Available: https://www2.deloitte.com/insights/us/en/focus/disruptive-strategy-patternscase-studies/anticipating-disruptive-strategy-of-market-entrants.html.

[26] R. Helyer, "Learning through reflection: the critical role of reflection in work-based learning (WBL)," J. Work. Manag., vol. 7, no. 1, pp. 15-27, Jan. 2015, doi: 10.1108/jwam10-2015-003. https://doi.org/10.1108/jwam-10-2015-003

[27] J. P. Shonkoff et al., "The lifelong effects of early childhood adversity and toxic stress," Pediatrics, vol. 129, no. 1, 2012, doi: 10.1542/peds.2011-2663.

[28] H. Hardika, "Model Pembelajaran Transformatif Berbasis Learning How To Learn Untuk Peningkatan Kreativitas Belajar Mahasiswa," Madrasah, vol. 6, no. 2, p. 14, 2016, https:// doi.org/10.18860/jt.v6i2.3319.

[29] H. Hardika, D. U. Soraya, and A. E. Nur, "Analisis Kebutuhan dan Sumber Belajar Mahasiswa yang Adaptif terhadap Era Disruptif," Google Docs. Malang, Aug. 24, 2020, [Online]. Available: https://docs.google.com/spreadsheets/d/1aije74bKV7xp2KwaMH xOwfHZWFkCzsaJJk3C20 GMLk/edit?usp=drive web\&ouid $=117305086757144502965$ \&usp=embed facebook.

[30] K. G. Willink and J. M. Jacobs, "Teaching for change: Articulating, profiling, and assessing transformative learning through communicative capabilities," J. Transform. Educ., vol. 9, no. 3, pp. 143-164, Dec. 2011, https://doi.org/10.1177/1541344611436012.

[31] S. E. Manakane, "Lingkungan Sebagai Sumber Belajar Dalam Pengembangan Konsep Keruangan,” J. Geogr. Gea, vol. 11, no. 2, Dec. 2016, https://doi.org/10.17509/gea.v11i2. 1632.

[32] A. Kitchenham, "Jack Mezirow on Transformative Learning," in Encyclopedia of the Sciences of Learning, N. M. Seel, Ed. Boston, MA: Springer US, 2012, pp. 1659-1661. https://doi.org/10.1007/978-1-4419-1428-6 362

[33] F. A. Firdaus and A. Mariyat, "Humanistic Approach In Education According To Paulo Freire," At-Ta'dib, vol. 12, no. 2. p. 25, Dec. 30, 2017, https://doi.org/10.21111/attadib.v12i2.1264.

[34] D. Perin, "Facilitating student learning through contextualization: A review of evidence," Community Coll. Rev., vol. 39, no. 3, pp. 268-295, Jul. 2011, https://doi.org/10.1177/009 1552111416227.

[35] F. R. Sullivan, Creativity, Technology, and Learning: Theory for Classroom Practice. Taylor \& Francis, 2017.

[36] M. Cavallone, M. V. Ciasullo, J. Douglas, and R. Palumbo, "Framing higher education quality from a business perspective: setting the conditions for value co-creation," Stud. High. Educ., 2019, https://doi.org/10.1080/03075079.2019.1672644.

[37] A. Thornton and T. Clutton-Brock, "Social learning and the development of individual and group behaviour in mammal societies," Philosophical Transactions of the Royal Society B: Biological Sciences, vol. 366, no. 1567. pp. 978-987, 2011, https://doi.org/10.1098/rstb.20 10.0312 .

[38] M. Suraya, U. Dayati, and H. Hardika, "Pewarisan Nilai-Nilai Budaya Lokal Di Malang raya (Studi Kaus Paes Manten Style Malangan)," J. Pendidik. Teor. Penelitian, dan 
Pengemb., vol. 1, no. 8, pp. 1649-1658, Jun. 2016, https:// doi.org/10.1080/08841241.2020.1728465.

[39] K. K. Smørvik and M. K. Vespestad, "Bridging marketing and higher education: resource integration, co-creation and student learning," J. Mark. High. Educ., 2020, doi: 10.1080/08841241.2020.1728465.

[40] V. Terziev, "Factors Affecting the Process of Social Adaptation," Social Science Research Network, Rochester, NY, Jan. 2017. [Online]. Available: https://papers.ssrn.com /abstract $=3143186$.

[41] H. Hardika, E. Nur Aisyah, T. Kurniawan, and U. Negeri Malang, "Literacy about Covid19: Trending Words, News Sources, Compre-hension, and Community Curiosity in Perspectives Nonformal Edu-cation History Article,” J. Nonform. Educ., vol. 6, no. 2, pp. 161-167, Aug. 2020, doi: 10.15294/jne.v6i2.24898.

[42] M. K. Vespestad and K. K. Smørvik, "Co-Creation as a Tool to Overcome Cross-Cultural Differences in Educational Experiences?,” J. Hosp. Tour. Educ., vol. 32, no. 3, pp. 156166, Jul. 2020, https://doi.org/10.1080/10963758.2019.1685391.

[43] F. Nazarullail, Hardika, and E. S. Desyanty, "Pemberdayaan Masyarakat Melalui Program Ekowisata 'Lepen Adventure,'” J. Pendidik. Teor. Penelitian, Dan Pengemb., vol. 2, no. 8, pp. 1071-1076, Jun. 2017, doi: 10.17977/jptpp.v2i8.9821.

[44] A. M. Alzain, S. Clark, A. Jwaid, and G. Ireson, “Adaptive education based on learning styles: Are learning style instruments precise enough?” Int. J. Emerg. Technol. Learn., vol. 13, no. 9, pp. 41-52, 2018, https://doi.org/10.3991/ijet.v13i09.8554.

[45] D. Blazar and M. A. Kraft, "Teacher and Teaching Effects on Students' Attitudes and Behaviors," Educ. Eval. Policy Anal., vol. 39, no. 1, pp. 146-170, Dec. 2017, doi: 10.3102/0162373716670260.

[46] J. Juharyanto, S. Sultoni, I. Arifin, I. Bafadal, A. Nurabadi, and H. Hardika, "'Gethok Tular' as the Leadership Strategy of School Principals to Strengthen Multi-Stakeholder Forum Role in Improving the Quality of One-Roof Schools in Remote Areas in Indonesia," SAGE Open, vol. 10, no. 2, p. 215824402092437, Apr. 2020, https://doi.org/ $10.1177 / 2158244020924374$.

[47] N. Winstone and D. Carless, Designing Effective Feedback Processes in Higher Education. Routledge, 2019.

[48] M. Young, "Overcoming the crisis in curriculum theory: a knowledge-based approach," J. Curric. Stud., vol. 45, no. 2, pp. 101-118, Apr. 2013, doi: 10.1080/00220272.2013.764505.

[49] L. Darling-Hammond, L. Flook, C. Cook-Harvey, B. Barron, and D. Osher, "Implications for educational practice of the science of learning and development," Appl. Dev. Sci., vol. 24, no. 2, pp. 97-140, Jan. 2020, https://doi.org/10.1080/10888691.2018.1537791.

[50] A. Hasni, F. Bousadra, V. Belletête, A. Benabdallah, M. C. Nicole, and N. Dumais, "Trends in research on project-based science and technology teaching and learning at $\mathrm{K}$ 12 levels: a systematic review," Stud. Sci. Educ., vol. 52, no. 2, pp. 199-231, Jul. 2016, https://doi.org/10.1080/03057267.2016.1226573.

[51] J. Arthur and A. Peterson, "The Routledge companion to education," in The Routledge Companion to Education, 2013, pp. 1-400.

[52] I. W. Widiana, I. N. Jampel, and I. G. A. P. Prawini, "the Effectiveness of Communication Learning Activities Based on Tradisional Game Toward the Cognitive Process Dimension," J. Cakrawala Pendidik., vol. 37, no. 2, Jul. 2018, https://doi.org/10.21831/cp. v37i2.14091.

[53] S. Fan, H. Tian, and C. Sengul, "Self-optimization of coverage and capacity based on a fuzzy neural network with cooperative reinforcement learning," Eurasip J. Wirel. 
Commun. Netw., vol. 2014, no. 1, p. 57, Dec. 2014, https://doi.org/10.1186/1687-14992014-57.

[54] Z. Filmawada, H. Hardika, and S. Sucipto, "Peran Kader Pkk Sebagai Agen Perubahan Kebersihan Dan Kesehatan Lingkungan Melalui Pendampingan Program Bank Sampah," J. Pendidik. Nonform., vol. 13, no. 2, pp. 78-84, Sep. 2018, doi: 10.17977/UM041V13I2P78-84.

[55] K. Laeeq and Z. A. Memon, "An integrated model to enhance Virtual Learning Environments with current social networking perspective," Int. J. Emerg. Technol. Learn., vol. 13, no. 9, pp. 252-268, 2018, https://doi.org/10.3991/ijet.v13i09.8000

\section{$7 \quad$ Authors}

Hardika Hardika is a lecturer in the Non-formal Education Department Faculty of Education at Universitas Negeri Malang. He is also a member of the IEEE Publisher. $\mathrm{He}$ is the editor of several journals at Universitas Negeri Malang there is the Journal of Education Faculty of Education and International Research-Based Educational Journal Faculty of Education. He is a reviewer for the Annual International Conference of Education and Training (ICET) and International Conference on Early Childhood and Primary Education Faculty of Education Universitas Negeri Malang. $\mathrm{He}$ is also an active member of the Indonesian Non-Normal and Informal Educators Association, and member of the Indonesian Social Education Bachelor Association.

Eny Nur Aisyah is a lecturer in the Early Childhood Education Department Faculty of Education at Universitas Negeri Malang. She is also working as a consultant in early childhood education at Dunia Anak. She is a member of the National Association in Early Childhood Education. And also, as a reviewer of the Golden Age Journal at Islamic Bandung University in Indonesia and the researcher was concern about learning innovations.

R. Anggia Listyaningrum is a lecturer the Non-formal Education Department Faculty of Education at Universitas Negeri Malang. He is active in education studies and research in the family and management in social activities.

Article submitted 2021-01-20. Resubmitted 2021-02-27. Final acceptance 2021-02-27. Final version published as submitted by the authors. 